\title{
Factors that Influence Attitude of Artisanal Fishers towards Conservation Measures in Ekperiama (Ekperikiri), Niger Delta
}

\author{
Ngodigha, Sabina Alatari (Corresponding author) \\ Department of Agricultural Education, Isaac Jasper Boro College of Education, \\ Sagbama, Bayelsa State, Nigeria
}

Tel: 234-803-724-8664Ｅ-mail: alatari3004@gmail.com

\begin{abstract}
J. F. N Abowei
Department of Biological Sciences, Niger Delta University, Amassoma, Bayelsa, State, Nigeria
\end{abstract}

Tel: 234-806-404-7286Ｅ-mail: jfnabowei@yahoo.com

Received: May 18, 2015 Accepted: June 9, 2015 Published: December 11, 2015

doi:10.5296/jee.v6i2.7626 URL: http://dx.doi.org/10.5296/jee.v6i2.7626

\begin{abstract}
The study was conducted between September 2013 to April 2015 to determine Artisanal Fishers attitude towards conservation measures in Ekperiama formally known as Ekperikiri in the Niger Delta. With the aid of well-structured questionnaires the desired information were collected and analyzed. Total sample sizes of 260 respondents within the study area were interviewed. Structured questionnaire was divided into four sections to include: socio-psychological characteristics, business information, environmental issues, conservation/ management knowledge. Likert scale was used when applicable. Factor analysis was conducted with the items to determine if underlying construct existed in the sub-scale. Cronbach's alpha coefficient was used to measure reliability of data and correlation was applied to measure linear relationship between variables. Binary logistic regression technique was used to determine the impact of the independent variables on willingness to adopt fisheries conservation measures. From the analysis, socio-psychological, environmental and institutional barriers are the primary factors influencing fisher's participation in fisheries conservation programmes in Ekperiama, Ogbia creek. These factors include: fishing
\end{abstract}




\section{Macrothink}

Journal of Environment and Ecology ISSN 2157-6092 2015, Vol. 6, No. 2

experience, awareness, fishers relationship with community, cooperation amongst fishers, relationship with other communities and fishers positive attitude towards preserving nature.

Keywords: Conservation measures, Demographic, Fisheries, Influence, Niger Delta, Willingness 


\section{Introduction}

Artisanal or small-scale fisheries are 'traditional', fisheries that are mainly non- mechanised with low level of production Mathew (2003). However, they are the predominant fishery in tropical developing countries (Berkes, et. al., 2001). Fisheries play a very significant role in the national economy as food supplier, employment provider and income earner. Fish and fish products provide over $10 \mathrm{~kg}$ of protein per capita per annum, an equivalent of $40 \%$ of all animal protein consumed in the country (Sikoki and Otobotekere 1999). Apart from being cheap source of highly nutritive protein, it also contains other essential nutrients required by the body. The fisheries sub-sector is also a high foreign exchange earner generating about 20 million dollars annually through the export of shrimps alone and providing direct and secondary employment to more than one million Nigerians (Abowei and Hart, 2008).

The annual fish consumption/demand in Nigeria has been estimated to be over 1.3 million metric tons and the total domestic production is just about 450,000 metric tons per annum, Tsadu, et. al. (2006). This clearly indicates that the demand for fish exceeds supply. Fisheries in most coastal and estuarine ecosystem are either fully exploited (Abowei and Hart, 2008) or over exploited (Ajana,2003; Waribugo, 2005) due to development of more fishing gear ( Waribugo,2005; Ngodigha, et. al.,2011,2013) and mechanization of boats (Enin et al,1991; Waribugo, 2005 ;Ngodigha, et. al.,2011,2013).The intense fishing pressure arising from the increase in the number of fishers, Ngodigha, et. al (2011) as well as the incessant oil pollution in the coastal waters Abowei and Ogamba (2013), Jamabo and Ibim (2010) could have contributed to the dwindling fish catches in the Niger Delta. However, since fisheries resources are renewable, appropriate management strategies must be adopted to ensure their sustainability.

Various researches on behaviours that influence adopting conservation technologies have been conducted using two theories. These are; actor-network theory, and adoption-diffusion theory (Mendoza,2006). Actor-network theory suggests that a decision to adopt conservation or other practices occurs within a larger system than only individual actors and their immediate environments, while Adoption-diffusion models explain and predict human behaviour relative to the adoption and diffusion of technologies and practices. The four major sets of explanatory variables used by Nowak and Korshing (1981) in adoption-diffusion model after a comprehensive study of research findings are: Social-psychological, Farm structural, Ecological and Institutional. In the study of adoption of best management practices in the Louisiana dairy industry Rahelizatovo and Gillespie (2004) applied this method and Mendoza (2006) also used this method to study factors influencing participation in environmental stewardship programs: a case study of the agricultural and forestry sectors in Louisiana.

The capacity of artisanal fisheries to play its triple role of a food supplier, employment provider and income earner in the Nigerian economy depends on the willingness of the fishers that are fully involved in the industry to adopt appropriate conservation measures that will ensure sustainability of the fisheries sector. This study is therefore aimed at revealing the factors that influence the attitude of artisanal fishers to fisheries conservation measures in 
Ekperiama.

\section{Materials and Methods}

\subsection{Study Site}

The research was carried out in Ekperiama (Ekperikiri), a passage from Okoroama in Nembe Local Government Area, to Ogbia town in Ogbia LocalGovernment Area. The study site (Fig 1) is $51.5 \mathrm{~km}$ south of the capital, Yenagoa in Bayelsa State and is situated in the heart of the Niger Delta and is located on latitude $4^{0} 38^{\prime} 19^{\prime \prime} \mathrm{N}$ and longitude $6^{0} 17^{\prime} 46^{\prime \prime} \mathrm{E}$ of the equator, with an altitude of 110 meters(www.worldplaces.net).

Ekperiama is a sister community to Akakumama, Oruweiama and Kukukiri located around the Ogbia creek on the south-eastern part of Bayelsa State. All communities share very close ties, often participating in common fishing trips and other economic activities.

Ogbia creek is one of the tributaries of River Nun with substantial seasonal variations due to heavy rains and wind. The creek is tidal and it is characterized by both estuarine and freshwater macrophytes. The riparian vegetation is composed of a tree canopy made up of Rhizophora racemosa (Red mangrove) Raphia hokeri, Costus after, Bambosa vulgonis, Alchornia cordifolla, Alstonia boonei, submerged macrophytes which include, Eicchornia crassipes (water hyacinth), Nyphea lotus ( watere lily) Cytosperima senegalensis, Ludwiga erecta, Pistia stratiotes(water lettuce).Dry season is from November to April and the rainy season peaks in July-September. The annual rainfall of the Niger Delta ranges from $2000 \mathrm{~mm}$ - 3000mm per year (Abowei, 2000). The dry season lasts for four months (NovemberFebruary) with occasional rainfall. The creek is also subjected to pollutants from petroleum exploration and expliotation activities in the Niger Delta that may have impacts on the ecosystem (Jamabo and Ibim, 2010). 


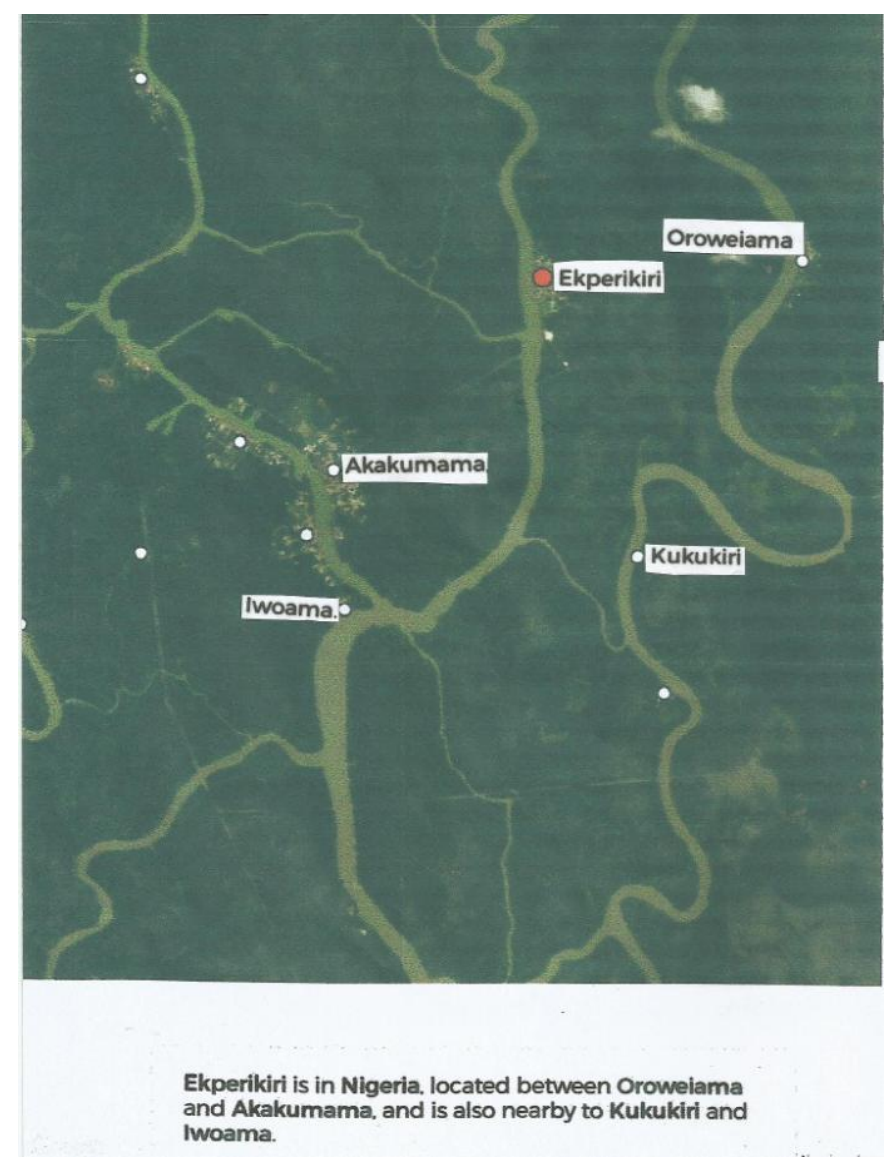

Figure 1. Map of study area

\subsection{Data Collection}

The adoption-diffusion model was used in this study. Measuring instrument used was a structured questionnaire developed based on existing literature and divided into four sections. Demographic characteristics, Business information, Environmental issues, Conservation/management knowledge

Likert-type scales were used when applicable. The 5-point rating scale used had rating of level ' 1 ' indicating strong dislike and was labelled 'strongly disagree", rating of level ' 2 ' indicating dislike was labelled 'disagree', level 3-agreement level, indicating ', agree to some extent", level 4- agreement level indicating "' agree" and level 5-agreement level represents "strongly agree". Information on the environment, resources, and their relationships with to the Sciaenid community were investigated during the surveys.

\subsection{Statistical Analysis}

The coded data were analysed using Statistical Package for the Social Sciences (SPSS) version 20 in the following ways:

- Factor analysis for construct confirmation and data reduction 


\section{Macrothink}

- Correlation analyses to test antecedents for factors influencing participation.

- Binary logistic regression

In all cases, the alpha level of statistical significance was set a priori at .05. Where necessary to interpret the magnitude of findings presented as correlation coefficients, the descriptors developed by Davis (1971) were used as follows:

$\cdot .70$ or higher indicates very strong association

$\cdot .50-.69$ indicates substantial association

- .30 - .49 indicates moderate association

$\cdot .10-.29$ indicates low association

$\cdot .01-.09$ indicates negligible association.

\subsection{Factor Analysis}

Factor analysis was conducted with the items to determine if underlying construct existed in the sub-scale. The method used was the principal components analysis with a varimax rotation. Anti-image correlation matrix was first used to determine the appropriateness of applying factor analysis. Measure of sample adequacy (MSA) was then examined. If the MSA's are above 0.50, factor analysis could be used (Hair, et. al., 1998) for the analysis.

The first step in conducting factor analysis was to determine appropriate number of factors to be extracted. A combination of latent root criterion and scree plot criterion were used to make this decision.

\subsubsection{Scale Reliability Testing}

Reliability refers to a measure's ability to yield consistent value if multiple values are taken over time. Factor analysis was used to determine the reliability of questionnaire (Hair, et .al., 1998).Item analysis was conducted to establish internal consistency and was calculated by using the Cronbach's Alpha Coefficient. Cronbach's alpha coefficient is a measure of reliability that range from 0 to 1 and the value of 0.6 is the generally acceptable lower limit (Hair, et. al., 1998). An alpha value greater than or equal to 0.7 is generally seen as a good indication of reliability of questionnaire (Hatcher, 1994).

\subsubsection{Validity}

Validity refers to the extent the measures correctly represents the concept or construct intended and how well the construct is defined by the measure (Hatcher,1994). Item loading of 0.5 is the lowest acceptable limit.

\subsubsection{Correlation Analysis}

Correlation is a measure of linear relationship between variables. A correlation coefficient of zero indicates no linear relationship exists. When the strength of association between two variables measured at interval or ratio level, Pearson's correlation coefficients is applied. 
Pearson's correlation requires parametric data because it is based upon the average deviation from the mean (Field, 2000). Spearman correlation coefficients are applied to non-parametric data (data is not measured at interval or ratio level and do not follow normal frequency distribution). Spearman correlation coefficient was used to measure the association between Fishers Participation in Conservation Programme and two variables (age and education) measured on ordinal level.

\subsubsection{Binary Logistic Regression}

Binary logistic regression is most useful when the event probability for a categorical response variable with two outcomes is to be model. The model is to determine if significant portion of the variance in the social-psychological, structural, environmental attitudes, and institutional incentives and barriers influence participation in fisheries conservation programme. Since the dependent variable (participation in fisheries conservation programme) is dichotomous in nature, it was as coded as " 1 " for participation and " 0 " for non-participation in fisheries conservation programme. Selected variables were entered into the analysis in a hierarchical manner. Social-psychological variables were entered in the first block to control for the effects of this variable on factors that influence participation. The structural variables were entered as the second block. These variables included both categorical and scale level variables that indicated the structure of the operation. The third block consisted of factors indicating respondents' environmental attitudes. The final block consisted of institutional barriers and incentives that respondents indicated in participation in fisheries conservation programme.

\section{Results}

\subsection{Socio-Psychological Relationships of Fishers}

The item with which the respondents had the highest level of importance was "Credit facilities" (mean $=3.97, \mathrm{SD}=1.21)$ and the lowest level of importance is "Good community relationship" (mean $=2.25, \mathrm{SD}=1.30)$.

Measure of sample adequacy of the socio-pyschological relationship (Table 1) shows acceptable values of all the factors, ranging from 0.655 to 0.854 . This indicates that factor analysis was appropriate for use with this scale. Two factors which accounted for $51.03 \%$ of the variance in the subscale were extracted with eigenvalue of 2.50. The high Cronbach's alphas (0.770) indicate that the measures are reliable and would yield consistent values in multiple measurements. From the results of the factor analysis, the items in the "Fishers Relationships" sub-scale were combined into a single score defined as the mean of the eight sub-scale items. The "Fisher Relationships" reliability score for the study participants was 0.770 .

Table 1. Fishers factor loading of relationship

\begin{tabular}{|l|l|}
\hline Relationship & Factor $1^{\mathrm{a}}$ loading \\
\hline Fishers cooperation & $0.854^{\mathrm{a}}$ \\
Good fishing industry & $0.851^{\mathrm{a}}$ \\
\hline
\end{tabular}


Legislators relationship

Extension services

Non-fishers relationship

Relationship with other communities

Credit facilities

Relationship with state legislators

Relationship with community

a Eigenvalue $=2.50$, Percent of Variance Explained $=53.44$

3.1.1 Relationship between Social-Psychological Characteristics of Fishers and Participation in Fisheries Conservation Measures

Results of the correlation analysis showed positive correlation between fishers participation in conservation programme and fishing experience $(\mathrm{r}=0.151$ "), marital status $(\mathrm{r}=0.441)$, fisher relationship (0.678") and gender $(\mathrm{r}=0.374)$. There are negative correlation between educational level $(\mathrm{r}=-0.091)$, age $(-0.139)$ and fishers participation. The two significant correlation is relationship score ( $0.861 ")$ and $\left(0.151^{\prime \prime}\right)$ as shown in Table 2.

Table 2. Relationship between Social-Psychological Characteristics and Participation in Fisheries conservation programme

\begin{tabular}{|l|l|l|l|}
\hline Socio-psychological Characteristics & $\mathrm{r}$ & $\mathrm{p}$ & $\mathrm{n}$ \\
\hline Fishing Experience & $0.151^{\prime \prime}$ & 0.698 & 260 \\
Marital Status & 0.441 & 0.234 & 260 \\
Gender & 0.374 & 0.322 & 260 \\
Fisher Relationship score & $0.678^{\prime}$, & 0.045 & 260 \\
Educational Level & -0.091 & 0.815 & 260 \\
Age & -0.139 & 0.720 & 260 \\
\hline
\end{tabular}

\subsection{Structural Variables}

The highest sales per week of artisanal fishers is between N10,100 and N20,000 (46.2\%), while the lowest is below N5,000 (2.3\%).A total of $55(21.2 \%)$ fishers sales per week is between N5,100 and N10,000; while $69(26.5 \%)$ fishers sales per week is above N20,000 and sales per week of $10(3.8 \%)$ fishers is between $\mathrm{N} 3,100$ and N5,000.

The highest number of trips made by the fishers in a week is above $9(43.1 \%)$ and the lowest is between 1 and 2 trips (3.5\%). $34.2 \%$ of the fishers have very good catch per week, while $24.2 \%$ have good catch per week. $17.7 \%$ feel the catch is very poor and $17.3 \%$ feel the catch is good to some extent. $4.2 \%$ of fishers are willing to take investment risk, while $88.5 \%$ avoid taking investment risk and $7.3 \%$ are willing to take some form of investment risk. A total of $199(76.5 \%)$ of fishers are willing to adopt conservation measures, while 61 (23.5\%) are not willing to adopt conservation methods. 
3.2.1 Relationship between Fisher Participation in Conservation Measures and Structural Variables

Result from the correlation analysis shows no significant relationship between structural variables and fishers participation in conservation programme (Table 3).

Table 3. Relationship between Structural variables and Participation in Fisheries conservation programme

\begin{tabular}{|l|l|l|l|}
\hline Structural variables & $\mathrm{r}$ & $\mathrm{p}$ & $\mathrm{n}$ \\
\hline Weekly sales & 0.036 & 0.926 & 260 \\
Weekly trips & 0.222 & 0.567 & 260 \\
Weekly catch & -0.168 & 0.665 & 260 \\
Investment risk & 0.443 & 0.232 & 260 \\
Household & 0.074 & 0.851 & 260 \\
Catch loss & -0.083 & 0.832 & 260 \\
Gear loss & -0.173 & 0.657 & 260 \\
Lack of storage facility & -0.356 & 0.347 & 260 \\
\hline
\end{tabular}

\subsection{Environmental Issues}

Fisher's response to New Environmental Paradigm statements portrays their attitude towards the environment. Statement 7(The balance of nature is strong enough to cope with the impacts of modern industrial nations) received the highest percentage of "somewhat agree" response, while statements 2 (Humans have the right to change the natural environment to suit their needs) and 8 (Despite our special abilities, humans are still subject to the laws of nature) have the highest and lowest percentage of "strongly disagree" respectively. Statement 4 (Humans are severely abusing the environment) have the highest percentage of "strongly agree", while statement 2 (Humans have the right to change the natural environment to suit their needs) have the lowest percentage of strongly agree.

3.3.1 Relationship between Fisher Participation in Conservation Measures and Environmental Issues

Results from the correlation analysis (Table 4) indicate a positive significant relationship between respondent's relationship and disastrous consequences when humans interfere with nature as an indicator of participation in fisheries conservation programmes. This factor explains 52 percent of the variance in the nine variables. Cronbach's alpha of 0.672 indicates that the measures are reliable and would yield consistent values in multiple measurements.

Table 4. Correlations between (NEP) Environmental Attitudes and Participation in Fisheries Conservation programme 
We are approaching the limit of the number of people the earth can support

Humans have the right to change the natural environment to suit their needs

When humans interfere with nature it often produces disastrous consequences

Humans are severely abusing the environment

The earth has plenty of natural resources if we just learn how to develop them

Plants and animals have as much right as humans to exist

The balance of nature is strong enough to cope with the impacts of modern industrial nations

Despite our special abilities, humans are still subject to the laws of nature

The so-called "ecological crisis" facing humankind has 0.504

0.167 260

$0.668^{\prime \prime}$

0.049

3.4 Relationship between Institutional Incentives and Barriers and Participation in fisheries conservation programmes

Findings showed one significant positive correlations between respondents relationship with other communities, $r=0.700$

Table 5. Relationship between Institutional Incentives and Barriers and Participation in fisheries conservation programme 


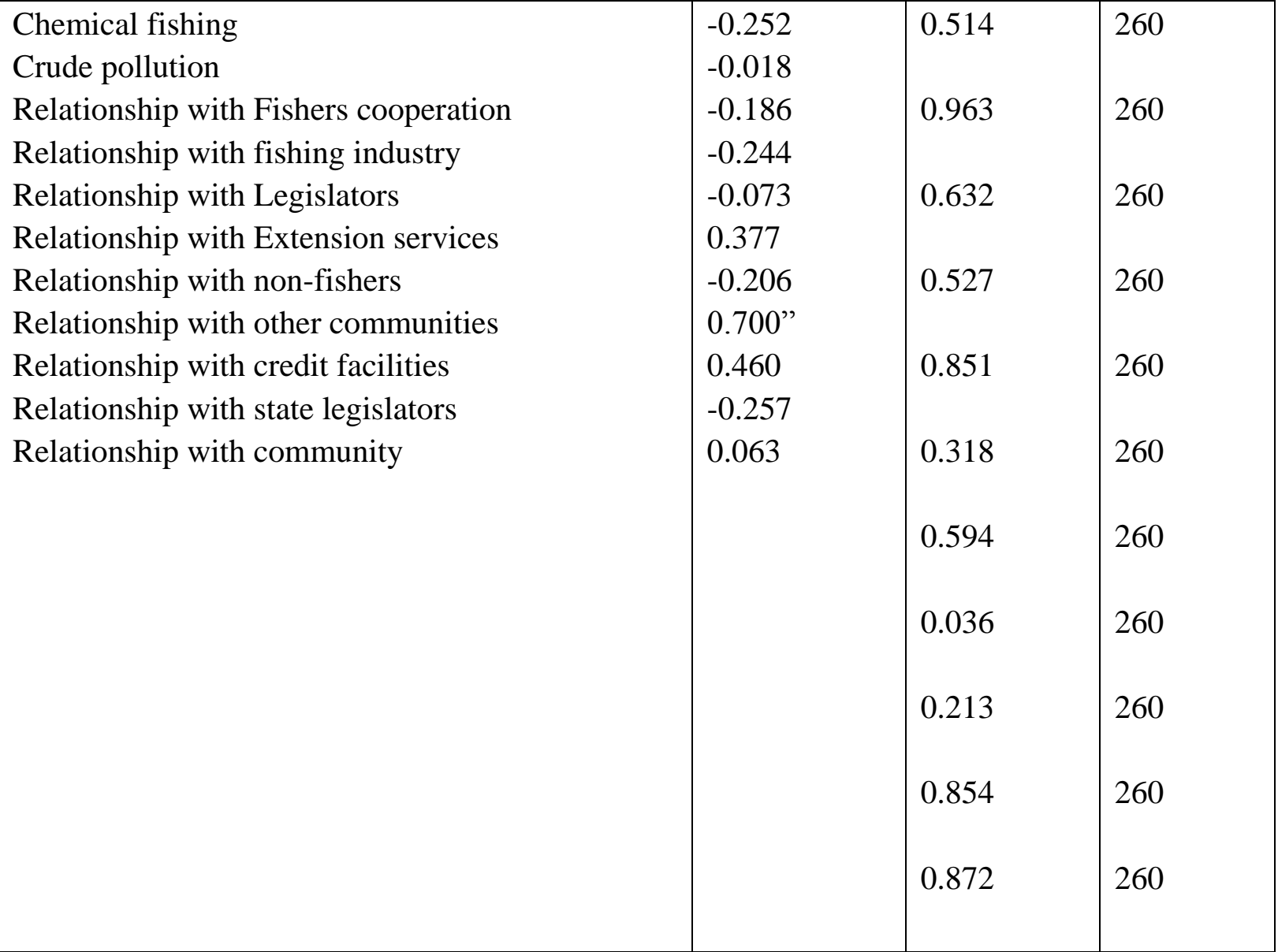

\subsection{Binary Logistic Regression}

Findings from the binary logistic regression analysis indicated that the control factor, participation in fisheries conservation Program was a significant contributor to the model (Wald $=49.288, \mathrm{p}=.000$ ). The Hosmer and Lemeshow test which indicates Goodness-of-fit has significant value greater than 0.05 , shows that the model adequately fits the data with a significant value of 0.768 . Twenty-five variables was entered into the model with an overall coefficient of determination $\left(\mathrm{R}^{2}\right)$ value of .585 (Nagelkerke $\left.\mathrm{R}^{2}=.585\right)$. This shows that about $60 \%$ of the variation is explained by the model.

The variable added to the model that has increase likelihood of participating in fisheries conservation programme are: step one, Awareness of fisheries conservation measures. Step two, cooperation amongst fishers and step three is Good community relationship .

The effectiveness of the model in correctly classifying subjects as to whether or not a respondent will participate in fisheries conservation Program. A total of 133 out of 136 YES cases (1.00) are correctly classified and 22 out of 37 of the NO cases (0.00) are correctly classified. Overall,79.3\% of the respondents included in the analysis were correctly classified using the identified statistically significant model.

Result of the correlation coefficients and binary regression analysis, indicates that socio-psychological, environmental and institutional barriers are the primary factors influencing fishers participation in fisheries conservation programmes in Ekperiama, along 
Ogbia creek. These factors include: fishing experience, awareness, fishers relationship with community, cooperation amongst fishers, relationship with other communities and fishers positive attitude towards preserving nature.

\section{Discussion}

The socio-psychological factor that affects fisher's adoption of fisheries conservation measures in this study is fishing experience. The findings agree with that of Akankali and Chinda (2011). Age as a factor reported by Carlson, et. al., (1981) has negative relationship with adoption, but Nowak and Korshing (1981) reported that younger people are more willing to adopt conservation technologies. This study also reveals that age has no effect on adoption of conservation measures rather experience influences fishers attitude towards adoption of conservation measures.

Fishers are willing to adopt conservation measures because they are conscious of the fact that human's interference with natural aquatic environment has produced disastrous consequences. This has lead to the poor state of the fishery due to chemical fishing and crude oil exploration and exploitation activities in the Niger Delta confirmed as critical constrains faced by fishers. Though the effect of oil exploration and exploitation activities has been highly publicised, creating the awareness on the effect of chemical fishing may reduce the use of chemicals to fish. Fishers might be willing to adopt this measure because as revealed in the correlation and confirmed in the binary logistic, there is a significant relationship between fishers willingness to adopt conservation measures and relationship score.

As revealed in this study, gender and level of educational attainment (Clearfield and Osborne 2003) have no significant effect on adoption of conservation measures, but, participation in local organizations (Abd-Ella et. al., 1981; Clearfield 1983; Korsching et .al. 1981). This could be due to the fact that fishing in Ekperiama is a part-time and full time occupation engaged by both sexes irrespective of age and educational qualification, but rather due to cooperation of fishers who are involved in the industry. They tend to understand the effect of managing the artisanal fisheries for maximum sustainability.

\section{Conclusion}

Based on the response of the artisanal fishers, it could be inferred that the willingness to adopt fisheries resources conservation measures in Ekperiama, Niger Delta, to a large extent is significantly a function of the studied Institutional Incentives and Barriers, environmental and socio-psychological factors. It is therefore pertinent to develop policies that will enhance these factors as highlighted in this research. This can be achieved by having frequent interactive sessions with the fishers to address the issue of depletion of the fisheries resources (Abowei, et. al., 2008, Ngodigh,et.al,2013). The application of scientific knowledge and of fisher's opinion will enhance the regions fisheries resources conservation which will eventually lead to ecological balance of the ecosystem, resulting in socio-economic stability and development. 


\section{References}

Abd-Ella, M. M., Eric, O. H., \& Richard, D. W. (1981). Adoption Behavior in Family Farm Systems: An Iowa Study. Rural. Sociology, 46, 42-61.

Abowei, J. F. N. (2000). Aspects of the fisheries of the lower Nun River. Ph. D. Dissertation, University of Port Harcourt, Port Harcourt 248.

Abowei, J. F. N., \& Hart, A. L. (2008).Artisanal fisheries characteristics of the fresh water reaches of lower Nun River, Niger Delta, Nigeria. Applied Science and Environmental Management, 12(1), 5 - 11.

Abowei, J. F. N., \& Ogamba, E. N. (2013). Effects of Water Pollution in Koluama Area, Niger Delta Area, Nigeria Fish Species Composition, Histology, Shrimp Fishery and Fishing Gear Type. Research Journal of Applied Sciences, Engineering and Technology, 6(3), 373-381.

Ajana, A. M. (2003). Economic Development of the Niger Delta: The Role of Fisheries. A Paper presented at the First Niger Delta Stakeholders Agricultural forum, Organized by Niger Delta Development Commission (NDDC), Port Harcourt.

Akankali, J. A., \& Chinda, A. (2011). Environmental, Demographic and Socioeconomic Factors Influencing Adoption of Fisheries Conservation Measures in Niger Delta, Nigeria. Research Journal of Environmental and Earth Sciences, 3(5), 578-586. ISSN: 2041-0492

Berkes, F. R., et al. (2001). Managing Small-scale Fisheries; Alternative Directions and Methods International Development Research Centre, Ottawa, Canada.

Carlson, J. E., Don, A. D., \& William, R. L. (1981). The Farmer and Erosion: Factors Influencing the Use of Control Practices. Bulletin, No. 601, Agricultural Experiment Station, University of Idaho, Moscow, Idaho.

Clearfield, F. (1983). Adoption of Conservation Practices: Review and New Findings. Paper presented at the Annual Meeting of the Rural Sociological Society, Lexington, Kentucky.

Clearfield, F., \& Osborn, B. T. (2003). Soil Conservation Services, The Case of No- Till Cropping. Rural Sociology, 68(2), 278-304.

Coates, D. (2000). Inland Fisheries and Enhancement Status, Constraints and Prospects for Food Security in Kyoto conference outcome and abstracts of papers.

Davis, J. A. (1971). Elementary Survey Analysis. Englewood Cliffs, NJ: Prentice-Hall.

Enin, I. U., Lowenberg, U., \& Kunzel, T. (1991). The Nematopalaemon hastatus ( estuarine prawn) fishery in the outer estuarine region of the Cross River, Nigeria. Arch.Fisch.Wiss, 41(1), 67-88.

Field, A. P. (2000). Discovering Statistics Using SPPS For Windows

Hair, J., et al. (1998). "Multivariate data analysis". 5th edition. Prentice-Hall, Inc. Upper Saddle River, New Jersey. ISBN 0-13-894858-5. 
Hatcher, L. (1994). A Step-by-Step Approach to Using the SAS System for Factor Analysis and Structural Equation Modelling, Cary, NC: The SAS Institute. Review.325-339.

Jamabo, N. A., \& Ibim, A. T. (2010). Utilization and Protection of the brackish water ecosystem of the Niger Delta for sustainable fisheries development. World Journal of Fisheries and Marine Science, 2(2), 138-141.

Korsching, P. F. (1981). A Comparison of Adopters of Conservation Practices with Traditional Innovation Adopter Categories. Paper presented at the Annual Meeting of the Rural Sociological Society, Guelph, Ontario, Canada.

Mathew, S. (2003). Small-scale fisheries perspectives on an ecosystem- based approach to fisheries management. In Responsible fisheries in the marine ecosystem. Edited by M. Sinclair and G. Valdimars- son. Cabi Publishing, Wallingford, UK. 47-63. [ISBN 0851996337].

Mendoza, C. C. (2006). Factors influencing participation in environmental stewardship programs: A case study of the Agricultural and forestry sectors in Louisiana, USA. A Ph.D. Dissertation, Graduate Faculty of the Louisiana State University, USA.

Ngodigha, S. A. (2011). Composition, Intra-specific dietary relationship and Food Diversity of Palaemon Shrimp bycatch in River Nun Estuary, Niger Delta. African Journal of Agricultural Research and Development, 4(3), 130-135.

Ngodigha, S. A., Abowei, J. F. N., \& Gbarabe, R. (2013). Palaemon Fishery in River Nun Estuary, Bayelsa State, Niger Delta. African Science and Technology Journal, 7(1), 142-149.

Nowak, P. J. (1982). Applicability of an Adoption - Diffusion Model to Resource Conservation: A Supporting View - Paper presented at the Annual Meeting of the Rural Sociological Society, San Francisco, California. 1982b. Social Dimensions in the Adoption of Soil and Water Conservation Practices. Position paper prepared for the Soil Conservation Service.

Nowak, P. J., \& Korshing, F. (1981). Social and Institutional Factors Affecting the Adoption and Maintenance of Agricultural BMP'S. Journal paper No. J-10379, Iowa Agriculture and Home Economics Experiment Stations, Iowa State University, Ames, Iowa. 1985. Conservation Tillage: Revolution or Evolution? Soil and Water Conservation.

Rahelizatovo, N., C., \& Gillespie, J. M. (2004). The Adoption of Best Management Practices by Louisiana Dairy Producers. Agriculture and Applied Economics, Southern Agricultural Economics Association, 36(1), 229-240.

Sikoki, F. D., \& Otobotekere, A. J. T. (1999). Fisheries. In Alagoa E. C. Port Harcourt (Ed.), The land people of Bayelsa State Central Niger Delta (pp. 301-319).

Tsadu, S. M., Ojutiku, R. O., \& Vanyawale, A. (2006). A survey of fungal contamination of some fish species from Tagwai Daru, Minna, Niger State, Nigeria. Tropical Biosciences, 6. $1-5$. 


\section{Macrothink}

Waribugo, S. A. (2005). Aspects of the biology and fishery of some Palaemonid shrimps in River Nun Estuary, Bayelsa State, Niger Delta. M.Sc thesis.

\section{Copyright Disclaimer}

Copyright for this article is retained by the author(s), with first publication rights granted to the journal.

This is an open-access article distributed under the terms and conditions of the Creative Commons Attribution license (http://creativecommons.org/licenses/by/3.0/). 